\title{
Languages discourses in Australian middle-class schools: parent and student perspectives
}

\author{
Jan Wright, Ken Cruickshank \& Stephen Black
}

To cite this article: Jan Wright, Ken Cruickshank \& Stephen Black (2016): Languages discourses in Australian middle-class schools: parent and student perspectives, Discourse: Studies in the Cultural Politics of Education, DOI: 10.1080/01596306.2016.1232536

To link to this article: http://dx.doi.org/10.1080/01596306.2016.1232536

\section{册Published online: 26 Sep 2016.}

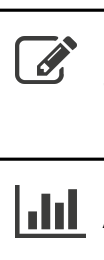

Submit your article to this journal $\pi$

لll Article views: 59

Q View related articles $ऍ$

View Crossmark data $\asymp$ 


\title{
Languages discourses in Australian middle-class schools: parent and student perspectives
}

\author{
Jan Wright ${ }^{\mathrm{a}}$, Ken Cruickshank ${ }^{\mathrm{b}}$ and Stephen Black ${ }^{\mathrm{c}}$ \\ ${ }^{\mathrm{a}}$ Faculty of Social Science, University of Wollongong, Wollongong, Australia; ${ }^{\mathrm{b}}$ Faculty of Education and Social \\ Work, The University of Sydney, Sydney, Australia; ${ }^{C}$ Faculty of Arts and Social Sciences, University of \\ Technology, Sydney, Australia
}

\begin{abstract}
Much of the literature on social class and language study in schools argues that for middle-class parents and their children, languages are chosen for their capacity to offer forms of distinction that provide an edge in the global labour market. In this paper, we draw on data collected from interviews with parents and children in middle-class schools in Australia to demonstrate how a complex amalgam of elite, cultural identity and/or trade language discourses came into play to explain the choice (or not) to study a language and the choice of specific languages. For many of the parents languages provided a limited form of 'civic multiculturalism', as a means of better understanding and respecting the 'other'. We argue that the value attributed to high status languages via this discourse, means their continued presence in schools hoping to attract middle-class parents, but their relative absence in schools with largely working-class populations, where more 'practical' concerns dominate.
\end{abstract}

\section{KEYWORDS}

Languages; social class; middle-class schools; language policy; linguistic capital; parents' and students' attitudes

\section{Introduction}

The relationship between language and social class is complex and very much related to the geopolitical context in which language policy is enacted (e.g. Gonzalez \& Melis, 2014; Rampton, Harris, Collins, \& Blommaert, 2008). In Australia, discourses associated with language provision in schools are integrally connected to Australia's history as a colony, its foreign policy and trade concerns, and as end point for immigration from Europe and more recently Asia and the Middle East (Clyne, 2005; Lo Bianco, 2008). In this, Australia is different from the UK where immigrant languages have only recently emerged on the policy agenda (Modood \& May, 2001), and from the US where heritage and modern language discourses remain separated and Spanish has primarily been the target of second language policy (Garcia, 2014).

In Australia, as in the US and the UK, language policy has been integrally caught up in relations of social class. European languages as 'foreign languages' traditionally acted as markers of distinction for the elite minority who completed the final years of schooling (Teese, 2013). With the growth of comprehensive schooling in the 1960s, languages 
became part of the curriculum for the increasing numbers who were completing secondary school and entering university. In comparison, minority or community languages, the languages of immigrant groups, were introduced into schools in the 1970s as a response to community needs within the overall policy of multiculturalism, providing opportunities for language maintenance and development for students of migrant background especially in working-class schools in the 1980s (Liddicoat, 2013; Lo Bianco, 2001; Teese \& Polesel, 2003).

Australian language policies since the 1980s have attempted to combine these two strands into a coherent language policy and to bring together the complex discourses of language under a 'languages for all' umbrella. To this mix was added the focus on languages for trade and career purposes (languages as human capital) stemming from the micro-economic reforms of the 1980s within the broader neo-liberal agenda. Despite these layers, these differences and the tensions that underpin language provision in Australia are neither fixed not straightforward. For example, some of the original community languages, such as Italian and Modern Greek, began in government low socioeconomic status (SES) schools but in the past decades have been taken up in middle-class schools. Policy shifts to privilege trade languages (see Council of Australian Governments (COAG) report, Government of Australia, 1994) have also seen some languages such as Chinese (Mandarin), first introduced as community languages, gain considerable status in elite private and academically selective government schools (Clyne, 2005). Languages associated with lower-SES groups, such as Arabic, Vietnamese and Turkish, without the appeal as trade or cultural languages, have remained marginal despite large numbers of speakers. As our research, reported in this and other papers (Black, Wright, \& Cruickshank, 2016; Cruickshank \& Wright, 2016), demonstrates language provision continues to widen the gap between a privileged middle-class child who attends a selective or independent school with a rich provision of language choices and working-class children attending comprehensive schools where language provision is severely limited.

In this paper, we focus on the provision of languages in middle-class schools. We draw on data from a larger study of language provision in New South Wales (NSW) schools (see Cruickshank \& Wright, 2016, for more detail), to argue that, despite arguments that for middle-class parents languages are primarily seen as a form of social and cultural capital with exchange value for employment in the global marketplace (e.g. Smala, Paz, \& Lingard, 2013), this is only part of the picture. As Vincent and her colleagues (Vincent, Rollock, Ball, \& Gillborn, 2012) suggest, the involvement, priorities and strategies with which middle-class parents engage with their children's schooling is not homogenous and the differences within class groups are important. While government policy discourse tends to ignore the complexities of language enactments in schools and the meanings that language study has for diverse groups of students and their parents, in this paper we demonstrate that there is no simple way in which to understand parents' and students' opportunities and choices in relation to language study, and that cultural and social capital in relation to language study are not simply associated with future employment or cultural identity.

\section{Inequalities in language provision}

Young people in Australia spend less time studying languages than young people in all other OECD countries (2014). However, as pointed out above, most languages studied 
by Australian students have been historically, and continue to be, very clearly differentiated by social class. In 2003, Teese and Polesel described this as a bipolar distribution in uptake, with languages such as French, German and Latin strong in high-SES schools and community languages strong in low-SES schools in areas where immigrant communities had settled.

The growth of comprehensive schooling in the 1980s promised that language study would be more widely spread, with many more students having access to languages so that by 2000, languages enrolments had increased by $500 \%$ (Teese \& Polesel, 2003, p. 92). With the introduction of community languages as secondary school subjects in the 1980s, language provision again grew exponentially. Modern Greek and Italian were the main languages, after English, spoken by school-aged students and these languages provided a key pathway for students in low-SES schools to develop their home language and access tertiary study. For example, $86 \%$ of students taking community languages in the state of Victoria in 1990 were in lower-SES secondary schools (Teese \& Polesel, 2003). Community languages sustained modern language study in these schools and without them it was predicted that 'language study will become a feature of a select few high SES government and independent primary and secondary schools retiring into the social enclaves represented by the most highly-educated Australian born families' (p. 92).

The adoption in 1994 of the COAG report (Government of Australia, 1994) signalled the dominant focus on economic goals for language learning. Four trade languages (Japanese, Mandarin, Indonesian and Korean) were nominated as having exclusive priority for federal funding. This changed the status of Asian languages from heritage/community languages to foreign languages, promoted to non-Asian students for Australia's economic benefit and the students' future employment. However, rather than broadening the range of languages available, Herriman (1996) argues that the key change was in a narrowness of focus and a construing of the goals of a policy in terms of clear economic and employment ends rather than ends of social justice, educational access and personal satisfaction' (Herriman, 1996, p. 52; quoted in Lo Bianco \& Slaughter, 2009, p. 23).

The period since 2000 has been marked by a shrinking of languages study to higher-SES government and independent schools and a marginalization of languages due to a range of factors which are beyond the scope of this article to explore. The trend, however, has followed Teese and Polesel's (2003) prediction, with social class distinctions continuing to be marked. The most popular languages in Australian schools in the past decade have been Japanese, Italian and Indonesian (DET, 2015; Liddicoat et al., 2007; Lo Bianco \& Slaughter, 2009). Traditional languages such as French continue to be strongest in 'elite' schools (Cruickshank \& Wright, 2016).

At the same time, however we would argue that what constitutes the 'elite' has become more differentiated to include a wider spectrum of the middle class, including an 'ethnic middle class' (Colic-Peisker, 2011). In response there has been an increase and diversification of middle-range independent schools although not, we should add, the most elite private schools, which have become increasingly mono-cultural (see Ho, 2015). These middle-range schools, together with government selective schools have come to cater for a more socially and culturally diverse middle class, some of which (e.g. language immersion schools) have included language study as one of their distinguishing features. At the same time selective government schools offer a less expensive alternative for middle 
class or aspiring middle-class parents and their children. In general these latter schools also offer considerably more languages than comprehensive government schools.

\section{Language as social and cultural capital}

In much of the sociological work on language, Bourdieu's (1991) concepts of cultural and social capital are invoked to explain the value of language to particular groups of people, such as cultural communities and/or for students (and their parents) making decisions about taking up second language study (Francis, Archer, \& Mau, 2009, 2010; Smala et al., 2013). The ways in which language can be understood as capital varies between and within these groups. For example, Francis et al. (2009) use the term 'ethnic capital' to distinguish between 'the mobilisation of a minoritised "community language" ... and the mobilization of foreign languages as capital more generally' (p. 527). In their study of Chinese complementary schools in the UK, it was only the middle-class students who described learning their community language as a form of social capital - that is, as having value in the Chinese as well as the global labour market. In the UK and in North America, studying languages can legitimately be understood as 'educational capital', that is capital that can facilitate entry into higher education or serve as an added credential. In Australia, this is less clearly the case. Few universities require a language for entry and, as is discussed below in more detail, the final matriculation exams in many states actively discourage the study of a language by some groups of people (e.g. background speakers of Asian and Arabic languages).

On the other hand, a more nebulous kind of social and cultural capital, not explicitly linked with opportunities in the global marketplace, but then also not excluding these, is the notion of languages as conveying a form of 'distinction' in the Bourdieuian sense (Bourdieu, 1984), by producing a particular kind of cosmopolitan/global citizen. While this idea is not new and has featured in the promotion of European languages in elite English speaking schools in the past, this has more recently been articulated in the context of the International Baccalaureate (IB) as the development of 'international mindedness'. The debates in the International Baccalaureate Organisation's (IBO) own literature point to the development of this idea from a western notion of a global culture to one which explicitly seeks to include 'non-Western linguistic, humanistic, scientific, mathematic and artistic cultures' (IBO, 2008; cited in Singh \& Qi, 2013). As Singh and Qi point out, the IBO says this latter endeavour is 'a challenging task' and one not necessarily evident in the ways the IB has been taken up in most/many schools. In their review of models and meanings of international mindedness for the IBO, Singh and Qi point out that whereas the 2009 definition 'largely equated international mindedness to global/intercultural understanding, the latest IB definition has incorporated two more dimensions, namely global engagement and multilingualism' (Singh \& Qi, 2013, p. viii). What this means is that students in all schools following an IB programme must begin the study of a second language at an early age.

As those critical of the IB suggest, however, in practice the kinds of education enacted in IB schools can act as a form of distinction that further marks differences between classes. In this case 'international mindedness' becomes a code for 'strategic cosmopolitanism' or the forms of multiculturalism - 'emotional multiculturalism, cognitive multiculturalism and socio-communicative multiculturalism' - valued by transnational corporations and thus a 
valued class attribute for economic advantage, responding to the needs of global capitalism, and thereby exacerbating inequalities and class differences (see Bunnell, 2010; Resnik, 2009, for a critical review).

While none of the schools in our study had adopted the IB, 'international mindedness' or their imaginings of their children as global citizens were often part of parents' explanations for the appeal of language study. What this meant, however, varied considerably from an instrumental view related to employment to one that had more in common with Resnik's (2009) notion of 'civic multiculturalism'. This latter position was also more evident in the ways in which languages were promoted by the schools in our study.

It is likely that this tendency to promote languages for membership of a global culture rather than for instrumental reasons was influenced by the nature of the schools that were included or rather not included in the study; schools we would describe as serving a notnecessarily affluent middle class. While data were collected from an independent grammar school (GS), an independent bilingual school (BS), and several government selective schools, we were unable to collect data from any of the private schools that have long histories of serving the elite, for example, member schools of the NSW Great Public Schools (GPS) or Associated Schools of NSW (CAS), and their girls' school equivalents. As we have suggested above, many of these schools follow longstanding traditions where classical languages such as Latin and Greek are taught, and languages are promoted as part of the 'cultured individual' to a primarily non-LBOTE student population (Ho, 2015). For example, from the Trinity GS Guide to Courses (Trinity Grammar School, 2015, p. 22), German and French are promoted as 'significant world languages and certainly any sojourn in Europe is greatly facilitated and enriched by knowledge of either language'. Many of these schools have now added Mandarin to their offerings. This leads to a situation where Mandarin as a trade/career language has high prestige but low prestige as a community language (see Cruickshank \& Wright, 2016). For the middle-class schools in our study the offerings were rarely quite so varied nor so substantial. Where languages were mentioned in the schools' websites, they were promoted more for their contribution to intercultural understanding, that is, the production of young people who through their exposure to other cultures and languages could see the world from different perspectives.

\section{Methodology and the larger study}

This paper draws on data collected for a large-scale Australian Research Council Linkage study 'Maximising Australia's Language Provisions: Exploring and Developing Language Resources across sectors, schools and communities' (2011-2015), involving three universities and all educational sectors in NSW, Australia. The larger study was designed to explore the ways languages have become implicated in the segmentation and divide along class and ethnic lines that have taken place in schooling. Data were collected from schools in inner Sydney, where almost 50\% speak a language other than English at home; and Wollongong, a regional city south of Sydney, where $15 \%$ speak a language other than English at home (Australian Bureau of Statistics, 2012). The third stage of the research involved case studies in 52 government, Catholic and independent primary and secondary schools and community languages schools. None of the elite schools we approached agreed to participate in the research. 
In the case study stage, data were collected in schools by a small team of researchers visiting the schools several times (at least three visits to each school). At each school the principal, the language teachers and, when available, non-language teachers were interviewed. All interviews were semi-structured, recorded and later transcribed in full. Small groups of students were interviewed in the manner of focus groups, with at least two researchers present. Parents were also interviewed individually or in small groups in their homes, at the schools, or at Parents and Citizens meetings. Language classes were observed, usually involving two researchers in the classroom taking field notes. These classes were not recorded. Research ethics approval for this study was obtained through the University of Sydney. The data presented in the following sections of this paper are based on the analysis of transcripts of interview with parents and students from the eight schools in our study we judged to fall into the category of middle-class schools on the basis of their Index of Community Socio-Educational Advantage (ICSEA) scores.

\section{The schools in our study}

In determining which of the schools in our study we would categorise as middle class, we looked at the ICSEA scores as well as demographics for the local area. In most cases these last were not so relevant to schools we identified because, except for the primary schools, students travelled to the schools from outside the local area. The ICSEA was 'created by the Australian Curriculum, Assessment and Reporting Authority (ACARA) specifically to enable fair comparisons of National Assessment Program - Literacy and Numeracy (NAPLAN) test achievement by students in schools across Australia' (ACARA, 2015, p. 1). The scores represent 'relative educational advantage' and are constructed taking into account both student (parents' occupation and education) and school level factors. 'ICSEA values typically range from approximately 500 (representing extremely educationally disadvantaged backgrounds) to about 1300 (representing schools with students with very educationally advantaged backgrounds)' (p. 1). We used the median ICSEA value of 1000 to distinguish between higher (middle class) and lower-SES schools in the study. However, to better capture the characteristics of languages schools with a clear middle-class demographic, we did not include schools that fell close to the median but instead included the schools that were 1100 or above for the analysis described in this paper.

The eight schools from which we drew data for this paper had ICSEA values ranging from 1097 to 1234. Three of the schools were selective government high schools and two specialist non-selective private schools - one an independent GS and the other a BS - all were coeducational. The remaining schools were two diocesan Catholic primary schools in relatively affluent areas and a regional Catholic Girls' College. The BS, the affluent Catholic primary school, the Catholic Girls' College had, according to the ACARA MySchool website, ${ }^{1}$ the lowest numbers of LBOTE (language background other than English) children (4\%, 3\% and 15\%, respectively), while two of the selective high schools had the highest ( $50 \%$ and $80 \%$ ). The remaining schools had between 25-30\% students from language backgrounds other than English. A LBOTE student is defined as one in whose home a language other than English is spoken. ${ }^{2}$ Despite the LBOTE data, parent's and children's responses in the interviews suggested that while English might have been the language spoken at home, many of the parents were second or third generation migrants often from language backgrounds other than English and with grandparents who still primarily spoke the community language. 
In the following section we describe and interpret results derived from the analysis of the interviews with parents and students at the middle-class schools in our study. The data were first coded broadly, using QSR Nvivo software, under the themes 'parents' perceptions of language education' and 'students' reasons for language study'. Following mapping data that indicated very clear differences in the distribution of language study between the selective and independent schools and the comprehensive lower-SES schools in the study (see Cruickshank \& Wright, 2016), social class was chosen as theoretical resource to examine how these differences featured in the data. One paper was developed to examine how social class played out in relation to language study in two of the working-class comprehensive schools (see Black et al., 2016). This paper in contrast focuses on the meanings attributed to language study in the middle-class schools, drawing on the theoretical resources of Bourdieu's notion of 'cultural capital' and the various interpretations of the concept of 'international mindedness'.

\section{Results}

In all of the high schools that we determined fell within the middle-class category in our study, the parents were making an active choice to send their child to this school rather than another. Attendance at these high schools meant travelling beyond their local area to the school, and in the case of the non-government schools, most charged substantial fees. The two diocesan primary schools were more likely to reflect the local demographics but still involved a choice away from local government schools. The choice of schools by families was in part, then, influenced by their own income but perhaps even more so by their aspirations for their children. While Smala et al. (2013) explain this in terms of 'the search for distinction and uniqueness, aspirations for social mobility and the global contest for jobs' (p. 373), we would argue that the parents' hopes for their children were more complex than this. While we cannot ignore the likelihood that part of the parents' motivation in sending their children to selective and non-government schools was because they believed this would provide the child with help with future study and advantage them in the labour market, for most of the parents we interviewed, their motivations were not quite so clearly instrumental. Rather the kinds of cultural capital the parents and the students in our study valued was not so much in terms of capital as exchange in relation to the labour market - that is, about giving them an edge - instead they talked about knowledge of a second language as providing the kinds of dispositions necessary for a citizen in a world characterized by diverse cultures, more what Resnik (2009) describes as civic multiculturalism. At the same time, the 'other' cultures often envisioned by the nonAsian-background parents were European cultures; cultures that would be experienced through travel and perhaps overseas study and work. There was a notable absence of any mention of African, Latino or Arabic cultures. The reasons for this bear further examination, which are beyond the scope of this paper.

\section{Languages as cultural capital: instrumental value (or not) of a second language}

Much of the sociological literature on the value of languages to middle-class students and parents, talks about 'linguistic capital' as a major reason for the study of a language, and particular languages. Smala et al. (2013), for example, argue that, 'linguistic capital' as a 
form of cultural capital is 'a marker of distinction linked to habitus and positioning within both a globalising and competitive labour market and emerging competitive school market' (p. 374). If we follow Bourdieu (Bourdieu, 1991; Bourdieu \& Passeron, 1990), this notion of linguistic capital assumes mastery of a language and the capability to deploy the language in those prestigious contexts in which it has exchange value; the language needs to be part of one's habitus. As we will discuss below, for most of the students and many of the parents in our study, they thought it unlikely that the students would be fluent in a language even if studied throughout their senior years. Rather the parents expected their children to have a good basis on which to build, and spending time in the country would be required to build fluency.

Rather than expecting fluency, the parents attributed other instrumental and indirect benefits to learning a language that were about 'expanding skills', or 'will look good on the CV', that is, forms of capital that would have a bearing on employment chances but not necessarily through fluency. They also imagined their children travelling later in life and language was seen as useful (having a language up one's 'sleeve' was a common comment) both to be able to converse with others as well as for seeking employment.

In our study, most of the talk about languages as linguistic capital or as having an instrumental value was associated with Asian and particularly Chinese languages, with Chinese often specifically named in relation to Australia's trade relations with China. For some few students and their parents there was also the specific value of preferential entrance or an improved entrance score for university study. As we discuss below and elsewhere (Cruickshank \& Wright, 2016), this only worked for some 'privileged' and what might be considered 'elite' languages - rarely for Asian languages.

While some of the students also made reference to the advantage of having a second language on their curriculum vitae, 'it looks good on your resume' (GS, year 10), they were rather vague about how this would play out, as exemplified in the following exchange between year 10 language students studying Italian at an independent GS:

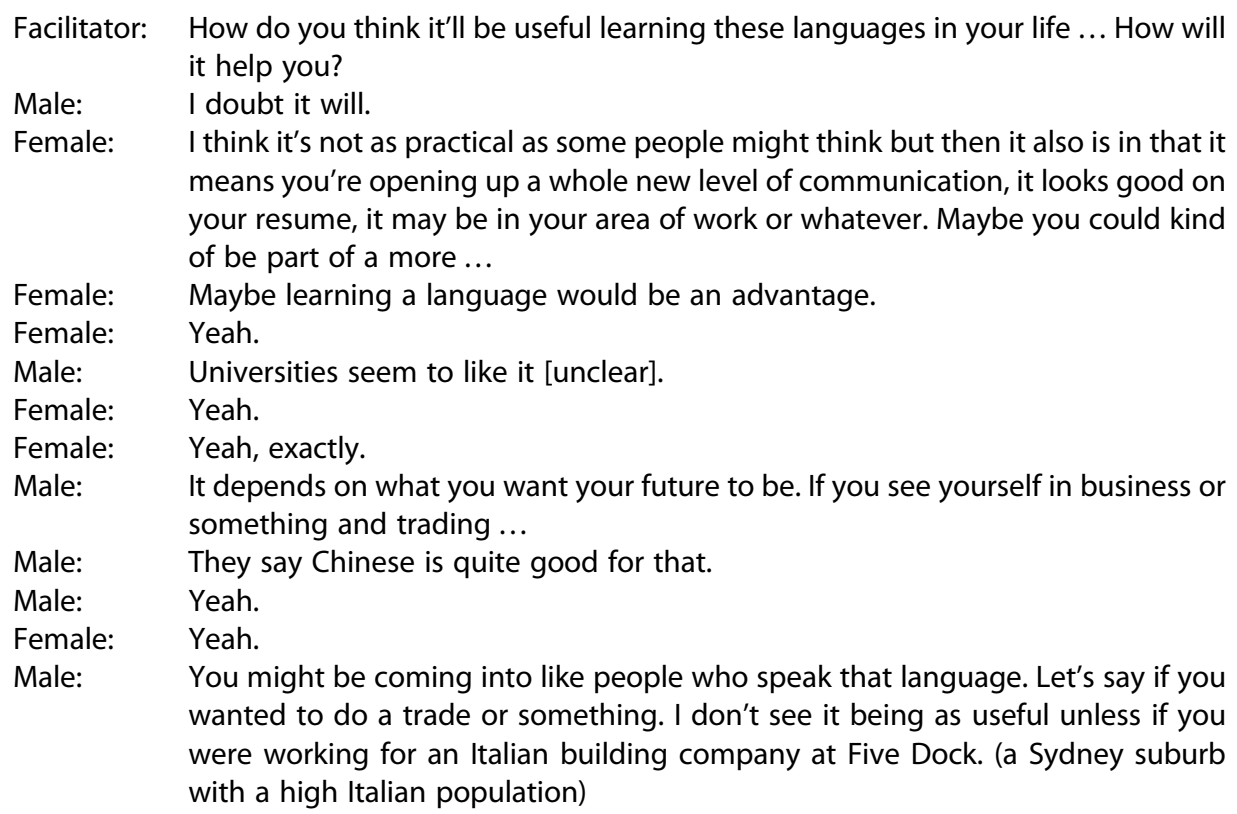


Surprisingly for these students from an international school, rather than studying a language (in this case Italian) for any utilitarian reason, it was 'more of a hobby'; they are not even sure that they will use it when travelling, 'Everyone learns English over there (in Europe) ... they'll realize you're not from France and they'll try to stop you as quickly as possible so that you can't massacre their language'. These doubts about fluency were not uncommon across the schools in the study particularly in the secondary schools, and many of the students could not imagine themselves being sufficiently fluent to use the language confidently with native speakers. They compared themselves disparagingly with exchange students' facility with English: 'my exchange student's English puts fear into me' and 'we can say nothing in Italian ... not compared to them' (GS student).

On the flip side was the perception, only hinted at by the parents and students from the middle-class schools, mostly when explaining why their peers did not take languages, that languages were of far less value for future occupations than extension study in mathematics and science. For the parents and students in our study, this influenced the decision to take or drop a language in the higher grades of schooling.

Well, it's certainly not the be-all and end-all. I don't think it's - I think Maths and English are more important. If they thought it was there, if they picked it up, they were encouraged and they were enjoying it, I certainly - I don't think it's absolutely critical because English is so - around the world. It's everybody else's second language. (Catholic primary school female parent)

In another case, a father was reported as having described language as a luxury his daughter 'could pick up at any time', whereas good results in the physical sciences and mathematics were requirements for study in medicine, engineering, and so on. In this case the young woman's passion for Italian won over, but because it was timetabled against Extension Mathematics she had to study the language externally (Catholic Girls' College).

In NSW there is considerable confusion and some practical reasons that would deter students who have studied language from year 7 to year 10 from continuing with their study to the final examination, the Higher School Certificate (HSC). Parents, teachers and students talked about how the scaling of languages pulled an Australian Tertiary Admission Rank (ATAR) down and how this discouraged the study of community and Asian languages. As is discussed below specifically in relation to Chinese, this is a wellfounded perception with community languages doing far less well in the scaling process compared to languages such as French, German and Latin (NSW Vice Chancellors Committee, 2015). However, for students who are likely to achieve very high marks in these languages and their other subjects this is not the case - although this seems to be rarely understood.

The anxiety over competitive entry to university particularly for the more prestigious programmes means that anything that might work against the highest possible score is likely to be abandoned despite students' interest in and often facility for studying a language (see also Cruickshank \& Wright, 2016). In addition, even where parents and students talked about language as an advantage in the global marketplace, ideas about the kinds of employment or careers made possible with additional languages were very vague. 


\section{Cultural capital: a 'cultured' disposition}

As suggested above, the parents, students and schools in our study talked about the value of studying a language in terms of better understanding the 'other', of being more of a global citizen with a world view that goes beyond the Anglo-centric which they see as common to many Australians. We wanted to characterize this as something more than an instrumental view of languages as cultural capital. At the same time we were mindful that there is considerable slippage between valuing a language so that one can communicate with others when travelling in Europe and learning a language that opens one's perspective to that of the 'other', including others who are from non-European or even non dominant Australian-Asian trading partners. There were no conversations, except in the most abstract form, that suggested Australian students might learn African or Arabic languages, despite the large numbers of immigrants from these countries in Australia. Resnik's (2009) notion of 'civic multiculturalism' captures something of the way some of the parents and the students talked about the value of learning another language. For Resnick, 'civic multiculturalism' involves 'learning about different cultures and the recognition of the "other"' (p. 220) and is the basis of the older form of multiculturalism that thrived in Australia in the 1970s and 1980s.

Despite the surprisingly low percentage of children who were categorized as not having English speaking backgrounds at GS and BS, most of the parents and students we interviewed at these schools and at the selective high schools came from families in which in which community languages were part of the environment, even if in many cases, rarely spoken in their own family home. The parents interviewed at the BS, for example, came from Hindi, Greek and Italian backgrounds. From the parents' perspective there was often a regret at not maintaining a community language and they were now pleased that their children were studying at least one language, whether this was their own community language or not. For many, this was about the kind of 'a civilized person' described by Resnik (2009). This is exemplified in the following exchange between two parents of a year 9 student at a government selective school, who had several languages and cultures between them:

Male parent: Well I think to learn a language you learn a culture as well. That seems to come along with it. I think for one thing that it's a great thing to learn because another culture is another viewpoint, another way of looking at the world in some ways.

Female parent: Yeah I do too. I just think end of the white bread Anglo - why wouldn't you want to learn another language? It feels like would you choose a smorgasbord or one meal? It just broadens and enriches your life speaking other languages. (Year 9 parents, selective government school)

For the students, languages also offered access to different cultures and different ways of being; it's 'cool' to be able to speak in another language. For the students we interviewed doing language beyond year 10 or in schools where language study from year 7-12 is a compulsory aspect of the school and in the case of BS a reason for attending the school, their enjoyment of languages was very evident.

Female: Yeah. Well I don't find it easy. I just find it kind of thrilling because it kind of opens up this whole kind of new way of communication which I just think is so cool. It 
Female: Yeah.

Male: I've never really seen a lot of practical use. I'm just enjoying it. It's just so intuitive. (GS, year 10 students)

\section{Cultural capital: choosing (or not) a community language}

Most of the conversations above have been about choosing a 'foreign' language, even where a language other than English was part of the family background. The only conversations about community languages in the middle-class schools that we studied were at a selective government school with a high population of Asian (Chinese) students. The reasons students gave for the study of Chinese up until year 10 were very similar to those of students in the Francis, Archer and Mau (2009) study of Chinese background students in England. To this point (that is, years 9 and 10), the students in our study explained their choice of Chinese (Mandarin) in terms of learning more about their own culture, the connection between language and their identity and for some its instrumental value in facilitating working for businesses in Australia where customers speak a Chinese language, as well as the opportunities suggested by 'the Asian century'.

Oh I chose Chinese just based on I wanted to learn more about my culture and the language involved. I speak Cantonese back home but they teach Mandarin at school and it will be more interesting if I learned a different dialect in Chinese especially now that Chinese is so commonly spoken as well. (Year 10 student, government selective school)

For the parents of these Chinese background students, again like the parents in Francis, Archer, and Mau's (2010) study, learning their community language (or least Mandarin) was important for its prestige and utility as a trade language. According to one Chinese background student, Chinese parents at the school 'almost force' their children to learn Chinese in the early years, so that they have a 'basic knowledge of Chinese'. However, in the final years of school, what mattered were subjects that would result in a high ATAR and entrée to prestigious professions. For these students this meant dropping Mandarin because of their classification as 'background speakers'. The ATAR scaling process results in Chinese (as well as other community languages) being scored far lower than the actual mark achieved in the HSC. This phenomenon had a powerful impact on the decisions of the Chinese students and their parents to continue with Chinese beyond Year 10 into the two preparation years for the HSC.

As a Year 7 student with Korean, French and Chinese heritage said, her parents were 'more concerned in the academics area' and what was important was 'doing well' and 'having a lot of opportunities'. In this scheme of things, 'languages [are not] that important'. Parents emphasized 'physics and chemistry, Chinese isn't important, it's not going to rank well' (Chinese background student). As a result Chinese classes at the school went from being full classes in year 10 to about four students in year 11 .

\section{Discussion and conclusion}

The results described above suggest that for the middle-class schools, parents and students in our study a complex amalgam of elite, cultural identity or trade language 
discourses came into play to explain the choice (or not) to study a language and the choice of specific languages. The rather negative/judgmental connotations attributed to the parents' desires for their children to study languages for instrumental gain and profit in other studies (e.g. Smala et al., 2013) are to some extent challenged. Languages were seen by the parents in our study to be a form of goods not simply for their exchange value but as part of being a contemporary citizen of the world. However as indicated in the debates around 'international mindedness', it is difficult to tease out the extent to which the parents' desire for their children to be more 'civilized citizens', and respectful of other cultures, can be disentangled from an instrumental trade discourse which associates cultural/social capital with the capacity to function as a global citizen who travels and has credentials for employment in the global market place. In addition, there is no way of ignoring that, as Block (2014, p. 134) points out, 'becoming a global citizen is very much a middle class aspiration', requiring economic, cultural and social capital, as well as the capacity to travel, far less available to working-class parents and their children.

At the same time, our analysis is complicated, we would suggest, by the specific social class and cultural heritage of many of the parents who participated in our study. We would argue that none of our schools could be described as catering for the elite - at least not the economic and social elite. Rather they catered for middle-class professionals who wanted academic excellence and a broader curriculum than most government comprehensive schools are able to offer (Campbell, Proctor, \& Sherington, 2009). Government selective schools are promoted, and promote themselves, as providing the opportunity for 'bright' students to reach their potential, and the GS and the BS offer forms of education that are 'alternatives' to comprehensive schooling including the opportunities to study another language from K-12 and, for the BS, immersion in another language. Many of our parents were second and third generation Australians who seemed to value learning [any] language because of their experiences of their own, often lost, heritage language. They continued to regard themselves and want for their children the opportunity to claim identities as multicultural citizens. This was less the case for parents from Chinese backgrounds for whom learning a Chinese language (Mandarin) combined a traditional discourse of language as identity, with that of Mandarin as a trade discourse offering openings for trade with China and future careers.

For the students we interviewed, the choice to take up or continue language study was much simpler. In all of the schools included in this paper, languages were valued and in most cases at least one language was mandatory until the end of year 10. The structure of our study also meant that the students we interviewed had all chosen to study a language beyond the mandatory hours. While the students recognized that, for their parents, studying a language might provide them with an edge for future employment, like students in many other studies (Fullarton \& Ainley, 2000; Liddicoat et al., 2007) most of them were studying a language or a specific language because they were good at them and derived pleasure from their study. Those beginning their study in secondary school were frustrated at the limited levels of achievement possible. Unless they were learning their own heritage language (and this was mostly the Chinese background students) they did not see themselves as fluent nor expected to be by the time they completed high school, so that imagining themselves as 'global citizens' who could easily converse in another language was difficult. They could imagine themselves using 
languages in a limited way when they travelled and perhaps as an advantage for work, but, rather surprisingly, rarely imagined using languages for interactions in Australia.

For most of the parents and students from the NSW schools in our study, languages were rarely regarded as providing academic capital. Indeed the opposite was likely to be the case. In NSW the study of languages as academic capital is highly constrained by the continuing elitism of the HSC/ATAR scaling regime, which impacts the decisions students and parents will make in relation to language study in the senior years (NSW Vice Chancellors' Committee, 2015; Teese, 2013). In NSW and other Australian states, the scaling structures of the HSC work for some languages (the elite European languages studied in the elite independent schools) and work against (or are perceived to work against) many others (including Asian languages), and so unless students are highly proficient or find considerable pleasure from language study, language enrolments decline markedly after year 10 (Lo Bianco \& Slaughter, 2009). This is a powerful factor impacting the study of languages even in those schools, except perhaps the elite independent schools, where language study is valued and supported in the junior years.

Finally what was absent from any of the conversation about studying languages in schools were references to languages other than the traditional European and Asian languages - none of the parents or the students made any comments to suggest that learning Arabic, for example, might have relevance in a country where Arabic is the third most commonly spoken language after English (ABS, 2012). This calls into question claims about the value of languages in promoting 'civic multiculturalism' or the capacity to see the world from the point of view of the 'other'. The Australian cultural imaginary for the parents and students in our study may have expanded to include some (very specific) Asian languages and cultures but did not, at least as far as our study suggests, include, for example, the cultures of Arabic and more recent African immigrants. Rather many parents continued to look nostalgically to Europe and European languages as ways of promoting 'international mindedness' and/or to Asian languages as heritage or trade languages.

This 'new' discourse, which suggests a limited form of 'civic multiculturalism', is a complex amalgam. It is mediated by issues of class in ways that seem to bypass recent policy discourse which privileges languages study for economic and employment ends. On the one hand, it is a discourse that values language study as a means to better understanding and respecting the 'other'. On the other, through its focus on the global rather than the local, it contributes to the marginalization of community languages in Australia and replaces an attachment to home languages with a broader attachment to languages of higher status - such as Chinese (Mandarin) and Italian. We would argue that the value attributed to high status languages via this discourse, means their continued presence in schools hoping to attract middle-class parents, but their relative absence in schools with largely working-class populations, where more 'practical' concerns associated with literacy and numeracy dominate (Thompson \& Harbaugh, 2013). This contributes to the differential distribution of the kinds of capital that the parents in our study clearly value for their children and which are generally denied children in comprehensive schools in Australia.

\section{Notes}

1. http://www.myschool.edu.au.

2. https://www.det.nsw.edu.au/media/downloads/ ... /lbote/lbote2011.pdf. 


\section{Disclosure statement}

No potential conflict of interest was reported by the authors.

\section{Funding}

Funding for this research was provided through an Australian Research Council Linkage Grant in partnership with the NSW Department of Education, CEO Sydney and Multicultural NSW.

\section{References}

Australian Bureau of Statistics. (2012). 2011 census. Media release. Retrieved November 18, 2015, from http://www.abs.gov.au/websitedbs/censushome.nsf/home/CO-60

Australian Curriculum, Assessment and Reporting Authority (ACARA). (2015). Guide to understanding ICSEA (Index of Community Socio-educational Advantage) values. Retrieved August 23, 2016, from http://www.acara.edu.au/_resources/Guide_to_understanding_ICSEA_values.pdf

Black, S., Wright, J., \& Cruickshank, K. (2016). The struggle for legitimacy: Language provision in two 'residual' comprehensive high schools in Australia. Critical Studies in Education. doi:10.1080/ 17508487.2016.1197139

Block, D. (2014). Social class in applied linguistics. London: Routledge.

Bourdieu, P. (1984). Distinction: A social critique of the judgement of taste. London: Routledge.

Bourdieu, P. (1991). Language and symbolic power (Ed. and Introduction by J. B. Thompson) (G. Raymond \& M. Adamson, Trans.). Cambridge, MA: Harvard University Press.

Bourdieu, P., \& Passeron, J. (1990). Reproduction in education, society and culture (2nd ed.). London: Sage.

Bunnell, T. (2010). The International Baccalaureate and a framework for class consciousness: The potential outcomes of a 'class-for-itself'. Discourse: Studies in the Cultural Politics of Education, 31 (3), 351-362.

Campbell, C., Proctor, H., \& Sherington, G. (2009). School choice: How parents negotiate the new school market in Australia. Sydney: Allen and Unwin.

Clyne, M. (2005). Australia's language potential. Sydney: UNSW Press.

Colic-Peisker, V. (2011). A new era in Australian multiculturalism? From working-class 'ethnics' to a 'multicultural middle-class'. International Migration Review, 45(3), 562-587.

Cruickshank, K., \& Wright, J. (2016). A tale of two cities: What the dickens happened to languages in NSW? Australian Review of Applied Linguistics, 39(1), 73-96.

Department of Education and Training (DET). (2015). Languages provision in Victorian government schools, 2014. Melbourne: DET.

Francis, B., Archer, L., \& Mau, A. (2009). Language as capital, or language as identity? Chinese complementary school pupils' perspectives on the purposes and benefits of complementary schools. British Educational Research Journal, 35(4), 519-538.

Francis, B., Archer, L., \& Mau, A. (2010). Parents' and teachers' constructions of the purposes of Chinese complementary schooling: 'Culture', identity and power. Race, Ethnicity and Education, 13(1), 101-117.

Fullarton, S., \& Ainley, J. (2000). Subject choice by students in year 12 in Australian secondary schools. LSAY Research Reports. Longitudinal surveys of Australian youth research (Report, No. 15). Melbourne: ACER. http://research.acer.edu.au/lsay_research/13

Garcia, O. (2014). U.S. Spanish and education: Global and local intersections. Review of Research in Education, 38(1), 58-80.

Gonzalez, R. D., \& Melis, I. (2014). Language ideologies: Critical perspectives on the official English movement, Vol. 2: History, theory and policy. New York, NY: Routledge.

Government of Australia. (1994). Asian languages and Australia's economic future. A report prepared for the Council of Australian Governments (COAG). Retrieved November 13, 2015, from http://apo. org.au/files/Resource/coag_asianlanguagesandaustraliaseconomicfuture_february1994.pdf 
Herriman, M. (1996). Language policy in Australia. In M. Herriman \& B. Burnaby (Eds.), Langauge policy in English-dominant countries (pp. 35-62). Clevedon: Multilingual Matters.

Ho, C. (2015). 'People like us.' Australian review of Public Affairs, Retrieved November 13, 2015, http:// www.australianreview.net/digest/2015/08/ho.html

Liddicoat, A. (2013). Language-in-education: The discursive construction of intercultural relations. Bristol: Multilingual Matters.

Liddicoat, A. J., Scarino, A., Curnow, T. J., Kohler, M., Scrimgeour, A., \& Morgan, A.-M. (2007). Investigation of the state and nature of languages in Australian schools: RCLCES. Canberra: Department of Education, Employment and Workplace Relations, University of South Australia.

Lo Bianco, J. (2001). From policy to anti-policy: How fear of language rights took policy making out of community hands. In J. Lo Bianco \& R. Wickert (Eds.), Australian policy activism in language and literacy (pp. 13-44). Melbourne: Language Australia.

Lo Bianco, J. (2008). Language policy and education in Australia. In S. May \& N. Hornberger (Eds.), Encyclopedia of language and education (2nd ed., Vol. 1, pp. 343-353). New York, NY: Springer.

Lo Bianco, J., \& Slaughter, Y. (2009). Second languages and Australian schooling. Victoria: ACER.

Modood, T., \& May, S. (2001). Multiculturalism and education in Britain: An internally contested debate. International Journal of Educational Research, 35(3), 305-317.

NSW Vice Chancellors' Committee. (2015). Report on the scaling of the 2014 NSW Higher School Certificate. Technical Committee on scaling. Sydney: Universities Admissions Centre.

OECD. (2014). Education at a glance: Highlights. Paris: OECD.

Rampton, B., Harris, R., Collins, J., \& Blommaert, J. (2008). Language, class and education. In S. May \& N. Hornberger (Eds.), Encyclopedia of language and education (pp. 71-81). Berlin: Springer Science + Business Media LLC.

Resnik, J. (2009). Multicultural education - Good for business but not for the state? The IB curriculum and global capitalism. British Journal of Educational Studies, 57(3), 217-244.

Singh, M., \& Qi, J. (2013). 21st century international mindedness: An exploratory study of its conceptualisation and assessment. The Hague: International Baccalaureate Organization. Retrieved from https://www.uws.edu.au/_data/assets/pdf_file/0007/558529/21st_Century_International_ Mindedness.pdf

Smala, S., Paz, J. B., \& Lingard, B. (2013). Languages, cultural capital and school choice: Distinction and second-language immersion programmes. British Journal of Sociology of Education, 34(3), 373-391.

Teese, R. (2013). Academic success and social power: Examinations and inequality (2nd ed.). North Melbourne: Australian Scholarly Publishing.

Teese, R., \& Polesel, J. (2003). Undemocratic schooling: Equity and quality in mass secondary education in Australia. Melbourne: Melbourne University Press.

Thompson, G., \& Harbaugh, A. (2013). A preliminary analysis of teacher perceptions of the effects of NAPLAN on pedagogy and curriculum. The Australian Educational Researcher, 40(3), 299-314.

Trinity Grammar School. (2015). Trinity Grammar School guide to courses. Retrieved from http:// shadrach.trinity.nsw.edu.au/1_senior/docs/academic_courses_8-10.pdf

Vincent, C., Rollock, N., Ball, S., \& Gillborn, D. (2012). Being strategic, being watchful, being determined: Black middle-class parents and schooling. British Journal of Sociology of Education, 33(3), 337-354. 